\title{
THE ANCIENT DRUG OPIUM
}

\section{Julyan \& M Dircksen (North-West University)}

The use of papaver somniferum (from the Latin fero ferre $=$ 'to bear/bring' and somnium = 'sleep') as a narcotic, goes back to the $13^{\text {th }}$ century BC. The works of ancient authors such as Dioscorides, Celsus, Galen, Theophrastus and Pliny the Elder provide us with detailed information about the morphology of the plant, its processing and the administration of the drug. ${ }^{1}$ These authors make it clear that opium was mainly employed as anodyne and narcotic but they also documented its use as a drug in the treatment of a variety of ailments, either as one of many ingredients in a medicinal recipe or as the main ingredient. Modern botanical and pharmaceutical analysis of the plant and its active ingredients provide us with some surprising conclusions regarding its effectiveness in the treatment of the medical conditions for which it was prescribed in the $1^{\text {st }}$ and $2^{\text {nd }}$ century.

A $775 \mathrm{~mm}$ high statuette (Fig. 1) of a Minoan $\left(13^{\text {th }}\right.$ century BC) goddess with uplifted hands probably provides us with the oldest ancient evidence for poppy and opium. It is known as 'The Poppy Goddess' because it bears on the head three movable pins in the likeness of heads of the sleep-inducing poppy (Kerényi 1976:24; Sakellarakis, 1987:91). It can be seen in the Museum at Herakleion. Greek archaeologists have concluded that:

1. The vertical notches in the capsules are more deeply coloured, and relate to the extraction of the juice.

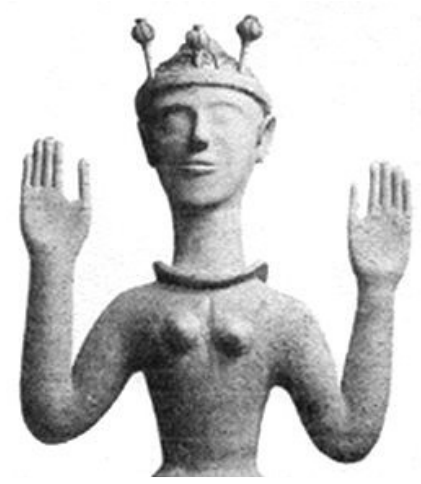

Fig. 1: Minoan poppy goddess ${ }^{2}$

2. The Minoan goddess appears to have her eyes closed as though asleep.

1 References to the information supplied by these sources will be found throughout this article.

2 http://www/ou.edu/finearts/art/ahi4913/aegeanhtml/minoansculpture.html.

Kerényi 1976:24, fig. 15. 
3. The folds in the cheeks give a smiling effect and the lifelessness of the parting of the lips perhaps imitate the effects of the drug (Kritikos and Papadaki 1967:25-26)
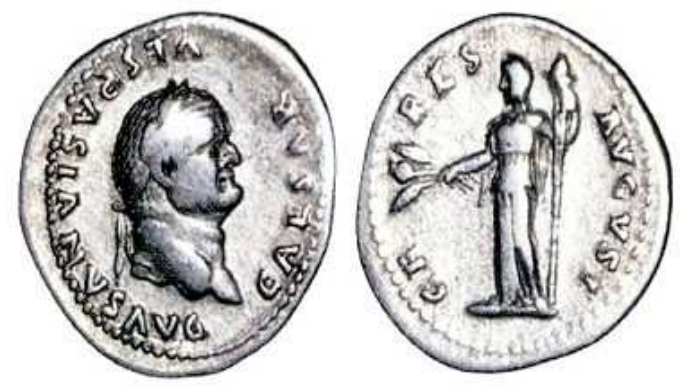

Fig. 2: Ceres and poppy ${ }^{3}$

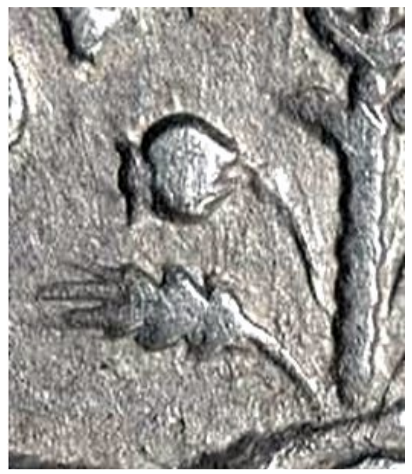

Fig. 3: Detail of poppy ${ }^{4}$
It is possible that this 'poppy goddess' has some connection with Demeter (whose Roman equivalent is Ceres), the goddess of agriculture, since poppies were certainly one of Demeter's sacred symbols. Legend has it that Demeter gave Celeus' sick son, Triptolemus, poppies to drink in warm milk to make him sleep (Ovid, Fasti, 4, 481483). Triptolemus was later the first to sow seeds and cultivate the fields (Ovid, Fasti, 4, 493-494). The poppy became one of the symbols of this goddess (Fig. 2) and she is often portrayed in combination with ears of corn. The theory is that they commonly grew amongst the grain crops since the seeds are stimulated to germinate by

3 This denarius (RIC-968) portraying Vespasian with a laurel wreath was minted in Rome AD 77-78. The inscription reads: CAESAR VESPASIANVS AVG. The coin reverse is part of the agrarian series Vespasian issued in the last half of his reign. It reads: CERES AVGVST and portrays Ceres holding corn ears, a poppy and a scepter.

http://www.forumancientcoins.com/gallery/displayimage.php?album=241\&pos=57 (accessed 12 Aug. 2011.)

4 From the reverse of a silver denarius of Vespasian, AD 69-79 (RIC II 55). Two clasped hands hold a caduceus, two poppy heads and two corn ears.

http://www.forumancientcoins.com/moonmoth/coins/vespasian_002. Date of access 12 August 2011. 
scratching and scraping such as is caused by ploughing.

There are also numerous references to poppy in ancient literature of which the oldest $\left(8^{\text {th }}\right.$ century BC), is probably from Hesiod (Theog. 125:212) and Homer (Iliad Books 8 \& 14). Hippocrates (460-377 or 355 BC) frequently mentions the poppy as being used in medicinal preparations especially as a hypnotic or narcotic drug (Kapoor 1995:13); Herakleides of Pontus (Fr. Hist. Gr. 2.215, Fragment 9.3) refers to its use in connection with euthanasia and we also find the poppy mentioned in Aristotle (384-322 BC) as a hypnotic drug (Sneader 2005:90). Virgil in his Georgics (1.208) says that autumn is the time to hide your crop of flax and the poppy of Ceres in the ground.

\section{Ancient authors on poppy and its medicinal properties}

\section{$2.1 \quad$ Morphology}

Dioscorides (4.64.1) identified one cultivated species (thylacitis) with an oblong head and white seed which is baked into bread or used with honey as part of a health inducing diet. He mentions two wild species of poppy with black seed, one of which he refers to as Papaver pithitis (Greek for 'jar') or rhoeas (= 'of the stream, flow' because of the drops flowing from the capsule when incisions are made into it), and another which is wilder, smaller, and more medicinal. Pliny also distinguishes between the cultivated poppy which is larger than the wild variety and displays a round head, and the wild variety with its oblong and small head. He asserts that the latter is more effective for all purposes than the cultivated kind (HN 6.20.76.202) and remarks on the irregular raven scratchings on the stem of the plant (HN 413.30.98).

Theophrastus says that the stem grows about a cubit high, the root is stout and shallow and the fruit is twisted like a little horn. The species known as ${ }^{5}$ rhoias, is similar to wild chicory, is edible and produces a red flower, and a head as large as a man's finger-nail. It is gathered before the barley-harvest, when it is still somewhat green (HP 9.12.4).

$5 \quad$ See Plin. $H N$ 4.14.167 - 169; Diosc. 4.64.1. 
Dioscorides gives a detailed description of poppy juice. The best kind produces latex (opos) which is thick and heavy and is soporific to the smell, bitter to the taste, easily diluted in water, smooth, white, neither rough nor full of lumps with a consistency similar to that of wax (4.64.5). Theophrastus adds that the juice is milky, as that of the fig (HP 1.12.2).

\subsection{Processing}

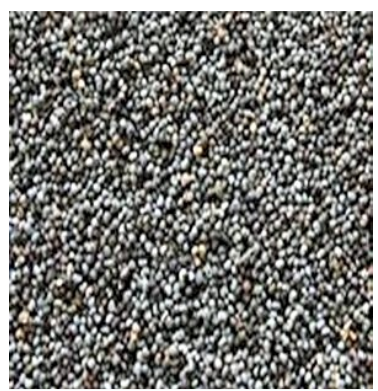

Fig. 4: Poppy seed ${ }^{6}$

Dioscorides (4.64.2) describes the two most used methods to process poppy:

First, one could beat the capsules together with the leaves and squeeze this substance through a press, pound it in a mortar, and then fashion lozenges; this was called meconium, but was considered less efficacious than the pure juice or latex; Pliny agrees that meconium is much weaker than opium (HN 6.20.76.202).
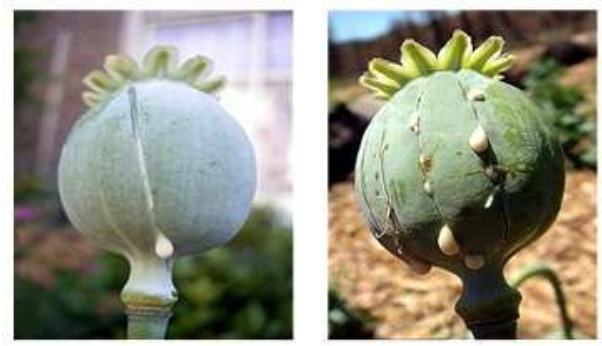

Fig. 5: Opium latex ${ }^{7}$

Second, to extract the latex itself, the ancients made incisions into the capsule with a knife (a procedure still in use in modern times), and taking care not to cut too deeply, they collected the tear that came out into a sea-mussel shell (myax). Dioscorides recommends the time of day when the dew has already evaporated for collecting the tears. ${ }^{8}$ He also warns that one should stand back when cutting the capsule so that the latex is not attached to one's clothing. After a short time the capsule will produce another congealed tear for collection and another is to be

www.fotosearch.com/photos-images/poppy-seed.html (Royalty free images).

www.drugs-forum.com

Modern botanists, employing ontogenic variation, have come to the same conclusion: it is best to make incisions in the afternoon when the poppy tears contain most opium. 
found on the following day; this juice was pounded up in a mortar and made into lozenges, sun dried for storage, and melted down again for use. ${ }^{9}$ The same method was employed to make lozenges from meconium, but in this case the pounded poppy capsules were boiled down in water to half the original volume, and then boiled again with honey until 'the moisture condensed out' (4.64.2).

Pliny provides information on the best ways to test for opium: the easiest and most obvious test was to smell the substance since the smell of pure opium is unbearable; the next best test is to put the opium in a lamp, where it should burn with a bright, clear flame and give off a smell only when it has gone out; Pliny regards the fact that pure opium is detected by the summer sun as especially noteworthy. He tells us that pure opium sweats and melts until it becomes like freshly gathered juice. Mnesides ${ }^{10}$ thought that opium was best stored when the seed of hyoscyamus was added ( $H N$ 6.20.76.203).

\subsection{Administering the drug}

There were different ways of administering the drug.

2.3.1 The lozenges were remelted for use in a decoction of the leaves and capsules. However, Celsus does not recommend the use of poppy in the form of pills:

Catapotia quoque multa sunt, variisque de causis fiunt. Anodyna vocant, quae somno dolorem levant; quibus uti, nisi nimia necessitas urget, alienum est: sunt enim ex vehementibus medicamentis et stomacho alienis (5.25.1).

Pills are also numerous, and are made for various purposes. Those which relieve pain through sleep are called anodynes; unless there is overwhelming necessity, it is improper to use them; for they are composed of medicaments which are very active and alien to the stomach. ${ }^{11}$

2.3.2 The seed of the poppy was ground up, mixed with water and plastered on the forehead and temples of insomniacs:

$9 \quad$ See also Plin. HN 6.20.76.198.

10 Likely the same as the Mnesidimos mentioned in Diosc. 4.64 (Scarborough 1995:19). Mnesidimos was an unknown Hellenistic physician, who appears to have been a noted authority on the opium poppy.

11 All translations are from the Loeb Classical Library. 
Papaveris ... idque in linteolum inlinere, et fronti adglutinare, ut conpressis venis pituitae impetum cohibeat ... Linteolo an lana excipiatur, nihil interest (Celsus 6.6.1).

Poppy ... then spread on lint and stuck on the forehead, in order that by compressing the veins the flow of rheum may be checked ... Whether it is spread on linen, or on wool, makes no difference.

2.3.3 It was also consumed: the leaves and capsules, boiled in water were taken orally for insomnia (Diosc.4.64.2; Celsus 5.25.3).

2.3.4 The face would be bathed in a decoction of the poppy heads either by using a sponge or soaked bread:

... Plurimi, decoctis papaveris corticibus, ex ea aqua spongia os et caput subinde fovent (Celsus 3.18.13).

Many foment the face and head at intervals with a sponge dipped in a decoction of poppy heads.

Si capitis dolores sint ... Iuvat etiam panis cum papavere iniectus, vel cum rosa, cerussa spumave argenti (Celsus 3.10.2).

If there is headache ... There is benefit from the application of bread soaked in poppy head decoction, or in rose oil containing cerussa or litharge.

2.3.5 To cure insomnia it was inserted as a suppository (Diosc. 4.64.4)

2.3.6 One could merely smell the thick juice (Diosc. 4.64.5).

2.3.7 It was also applied directly to the eyeball:

Superinungui vero oculi debent, sic ut croci quantum tribus digitis conprehendi potest, sumatur; murrae ad fabae, papaveris lacrimae ad lenticulae magnitudinem; eaque cum passo conterantur, et specillo super oculum inducantur (Celsus 6.6.1.H).

There should be smeared over the eyeball, of saffron as much as can be taken up in three fingers, of myrrh an amount the size of a bean, of poppy tears the size of a lentil: these are pounded up in raisin wine, and applied on a probe to the eyeball. 
2.4 Poppy's medicinal effects according to the ancient writers

\subsubsection{Sleep inducement and narcotic properties.}

Poppy was widely used in antiquity as a sleep-inducing herb (Diosc. 4.64.3; 4.64.4-5; Celsus 2.32; 5.25; Pliny $H N$ 5.18.59.229; 6.20.76.201) Illustrative is the following text form Celsus' De Medicina :

Si nihilo minus vigilant, quidam somnum moliuntur potui dando aquam, in qua papaver ... decocta sint (Celsus De Medicina 3.18.12).

If in spite of this patients are wakeful, some endeavour to induce sleep by draughts of decoction of poppy.

Often the ability of solanaceous plants to induce sleep was increased by the addition of the juices of the opium poppy (Celsus de Medicina 2.32) and when used in large quantities, poppy was employed as a narcotic (Pliny HN 5.18.61.229). A very popular remedy for bodily pains and insomnia amongst the ancient authors was theriac, a mixture made of several ingredients, including poppy extract and snake venom (Siegel 1976:134). Galen provides three recipes for the theriac (On Antidotes 15.5-15 K) which he prescribed for the emperor, Marcus Aurelius $(121-180 \mathrm{AD})$ to relieve his chest pains. Galen reports that theriac also cured the emperor's insomnia and severe body pains. ${ }^{12}$

Both Celsus (4.64.3) and Pliny warn that opium, used in immoderate quantities will plunge the patient into a coma and that it could cause death: ${ }^{13}$

Papaveris ... non vi soporifera modo, verum, si copiosior hauriatur, etiam mortifera per somnos. Opium vocant (HN 6.20.76.199).

Poppy juice is not only a soporific, but if too large a dose be swallowed the sleep even ends in death. It is called opium.

It is certain that poppy was employed as a suicide drug in ancient times, particularly by sickly elderly people $(H N$ 6.20.76.199; see also Cilliers et al. 2000:92).

Galen On antidotes 14.3-6 K; See also the article of Retief et al. 2007:56-65.

13 Galen was also aware of the risks attached to the excessive use of opium, cf. Africa 1961:98. 


\subsubsection{Pain relief}

Throughout antiquity, poppy was used for almost any aches and pains as an anodyne. Celsus (5.25.3-4) prescribes a mixture containing poppy tears to induce sleep and thus provide relief for a wide variety of ailments including headache, toothache, intestinal griping, pain in the hips, liver, spleen or ribs. Dioscorides also believed in poppy's analgesic effects (4.46.3) and prescribes poppy soaked with unguent of roses to treat headaches and instilled with unguent of almonds, saffron and myrrh in the case of earaches (4.64.4).

Celsus recommends the following treatment to ease the pain associated with toothache:

... In dentium autem dolore, qui ipse quoque maximis tormentis adnumerari potest, vinum ex toto circumcidendum est ... (6.8.9.1)

... Quod si gravior dolor est, utiliter et alvus ducitur, et calida cataplasmata super maxillas inponuntur, et ore umor calidus cum medicamentis aliquibus continetur, saepiusque mutatur. Cuius rei causa et quinquefolii radix in vino mixto coquitur, et hyoscyami radix vel in posca vel in vino, sic ut paulum his salis adiciatur et papaveris non nimium aridi cortices et mandragorae radix eodem modo. Sed in his tribus utique vitandum est, ne, quod haustum erit, devoretur (6.8.9.2).

...Quin etiam quaedam quasi cataplasmata in dentem ipsum inlinuntur ... Aut panacis, papaveris lacrimae, peucedani, uvae taminiae sine seminibus pares portiones conteruntur. Aut galbani partes tres, papaveris lacrimae pars quarta (6.8.9.3).

... Now in the case of pain in the teeth, which by itself also can be counted among the greatest of torments, wine must be eliminated.

... For more severe pain a clyster is useful, with a hot poultice upon the cheeks, ${ }^{14}$ and hot water containing certain medicaments held in the mouth and frequently changed. For this purpose cinquefoil root may be boiled in diluted wine, and hyoscyamus root either in vinegar and water, or in wine, with the addition of a little salt, also poppy-head skins not too dry and mandragora root in the same condition. But with these three remedies, the patient should carefully avoid swallowing the fluid in the mouth.

14 When the authors discussed the passage with John Scarborough, he suggested 'above the jaws' as a more accurate and suitable translation for super maxillas. 
... Moreover, some applications, like poultices, are smeared on the root itself.

... Or equal quantities of all-heal, poppy-tears, sulphur wort, and black bryony berries without the seeds are pounded together. Or three parts of galbanum to one of poppy juice.

Pliny mentions the use of poppy as a liniment for gout, and adds that even the leaves on their own, placed onto the inflamed parts will have the desired effect:

... Papaveris sativi ... Podagris inlinitur cum lacte mulierum, — sic et foliis ipsis utuntur (HN 6.20.76.201).

Of the cultivated poppy ... as a liniment for gout it is applied with woman's milk - the leaves by themselves are also used.

Dioscorides agrees with Pliny's sources as far as woman's milk is concerned when treating gout but he adds saffron to the recipe (4.64.4).

One recipe of which Pliny $(8.30 .22 .71)$ is the source, contains a spotted lizard to which is added three oboli of black poppy ${ }^{15}$ - a mixture which was considered most beneficial in the treatment of pains caused by sciatica. ${ }^{16}$

Celsus' similarly refers to a remedy containing poppy for the treatment of arthritic pains:

Ad dolores articulorum Sosagorae: plumbi combusti, papaveris lacrimae, corticis hyoscyami, styracis, peucedani, sebi, resinae, cerae, pares portiones $(5.18 .29)$.

The emollient of Sosagoras ${ }^{17}$ for pain in joints contains calcined lead, poppy tears, hyoscyamus bark, sulphurwort, suet, pine resin and beeswax, equal parts [trans. Spencer, Vol. 2 p. 28, slightly modified].

\subsubsection{Inflammation}

Dioscorides prescribes poppy mixed with a boiled egg yolk and saffron for eye inflammations (4.64.4). He cites four different sources (Diagoras, Erasistratos, Andreas and Mnesidamos) to support this claim, a clear indication of the

15 For purported effects of the wild poppy, see Plin. $H N$ 6.20.78.205-206. He also distinguishes a second $(H N 6.20 .79 .207)$ and a third variety $(H N 6.20 .80 .209)$ of wild poppy, tithymalon (mecon).

16 Pain felt down the back and outer side of the thigh, leg, and foot. It is usually caused by degeneration of an intervertebral disc, cf. Martin 2002:617.

17 No other reference to Sosagoras is found. His name is synonymous with this emollient. 
importance the ancients attached to this drug. He regards warnings that the unadulterated use of poppy in the eyes could cause blindness as decidedly false (4.64.6). We also find references to poppy's ability to relieve fluxes of the eye and the usefulness of the leaf to remove ulcers from the eyes of sheep in Pliny's work. ${ }^{18}$

Ear infections were similarly treated with poppy. ${ }^{19}$ Celsus supports this claim and recommends instilling poppy with unguent of almonds, saffron and myrrh:

Ea quoque medicamenta, quae oris exulcerati causa componuntur, atque aeque ulcera aurium sanant (Celsus 6.7.2A).

... Est Menophili validum admodum, quod ex his constat: piperis longi P. * I; castorei P.* II; murrae, croci, papaveris lacrimae, nardi Suriaci, turis, malicori, ex Aegyptia faba partis interioris nucum amararum, mellis quam optumi, singulorum P.*1111 (Celsus 6.7.2C).

... At si multum puris malusque odor est, aeruginis rasae, turis, singulorum P. * II; mellis cyathi duo; aceti quattuor simul incocuntur. Ubi utendum est, dulce vinum miscetur. Aut aluminis scissilis, papaveris lacrimae, acaciae suci par pondus miscetur, hisque adicitur hyoscyami suci dimidio minor quam unius ex superioribus portio, eaque trita ex vino diluuntur (Celsus 6.7.2D).

The medicaments which are compounded for ulcerations of the mouth are equally healing for ulcerations of the ear ...

...There is the very active remedy of Menophilus, which consists of: long pepper 4 grms; castoreum 8 grms.; myrrh, saffron, poppy-tears, Syrian nard, frankincense, pomegranate rind, the embryo of an Egyptian bean, bitter almonds, and the best honey 16 grms. each ...

... But when there is much pus, and bad odour, verdigris scrapings and frankincense 8 grms. each, honey $85 \mathrm{c.cm}$; vinegar $170 \mathrm{c.cm}$. are boiled together. For use, it is mixed with sweet wine. Or equal weights of shredded alum, poppy-tears and acacia juice are mixed together, and to these is added of hyoscyamus juice less than half the quantity of each one of above; and these are pounded together and diluted with wine.

Pliny prescribes poppy for inflammation of the sinews or of the intestines ${ }^{20}$ and Celsus includes poppy in his decoction for the treatment of inflammation of the womb (5.25.5) but warns against this remedy in the case of fever.

$18 H N$ 7.25.91.143.

19 Plin. $H N$ 8.32.25.77. 


\subsubsection{Colic, diarrhoea, and constipation}

Pliny (or his sources) had much faith in poppy's ability to relieve coeliac trouble. ${ }^{21}$ To ease the cramps the dark poppy was added to wine ${ }^{22}$ or mixed with powdered gentian. ${ }^{23}$ Looseness of the bowels could be treated with poppy mixed with powdered plantain ${ }^{24}$ while black poppy was regarded as a less violent emetic. ${ }^{25}$ For the treatment of dysentery poppy was to be mixed with eggs, the ash obtained from the egg shells and wine. ${ }^{26}$ The roasted liver of cocks or the skin of their crop, usually thrown away, mixed with dried poppy juice was used in the treatment of ileus. ${ }^{27}$ Poppy was also an ingredient in Celsus' medication for colic (5.25.12; 4.21.2) and indigestion (5.25). He believed that the juice would improve digestion, ${ }^{28}$ and provide relief for other abdominal conditions (4.64.3).

Both Pliny and Theophrastus refer to poppy's ability to purge 'upward' (by vomiting) and 'downwards" ${ }^{29}$ (by causing diarrhoea), while Dioscorides, on the contrary, prescribes the seed of the black poppy, ground up and given to drink with wine for the treatment of diarrhoea (4.64.3).

\subsubsection{Bladder pain and difficult urination}

To dull the pain and inhibit the inflammation and infection associated with difficult and painful urination Celsus recommends the following decoction:

Adversus urinae difficultatem piperis longi, castorei, murrae, galbani, papaveris lacrimae, croci, costi unciae singulae; styracis, resinae

20 Plin. $H N$ 6.22.58.123.

21 Plin. $H N$ 7.26.47.74.

$22 \quad H N$ 6.20.76.201.

23 Gentiana lutea L. and Gentiana purpurea L. were both used, see Beck 2005:432.

24 Plin. $H N$ 7.26.28.44.

25 Plin. $H N$ 7.26.40.67.

26 Plin. $H N$ 8.29.11.43.

27 Intestinal obstruction, usually obstruction of the small intestine (ileum), see Martin 2002:342.

28 The following recipe is one for relief of bad digestion:

Potest tamen etiam ad concoquendum, quod habet papaveris lacrimae, galbani, singulorum P. * I; murrae, castorei, piperis, singulorum P. * II. Ex quibus, quod ervi magnitudinem habet, satis est devorasse (Celsus 5.25).

There is one, however, which actually promotes digestion; it is composed of poppy tears and galbanum, 4 grms. each, myrrh, castory, and pepper, 8 grms. each. Of this it is enough to swallow an amount the size of a vetch. 
terebenthinae pondo sextantes, melabsinthi cyathus. Ex quibus ad magnitudinem fabae Aegyptiae et mane et cenato dari debet (5.25.16).

For painful urination long pepper, castory, myrrh, galbanum, poppy tears, saffron, costmary, 28 grms. each; storax and terebinth resin, ${ }^{30}$ 56 grms. each, honey with absinth $42 \mathrm{c.cm}$. Of this an amount the size of an Egyptian bean ${ }^{31}$ should be taken in the morning and after dinner.

Elsewhere he also comments that the pounded seeds of the plant will cause a discharge of urine..$^{32}$

\subsubsection{Bronchial problems}

The juice was also considered effective to suppress coughing as the following recipe of Celsus illustrates: ${ }^{33}$

Si tussis somnum prohibet, ad utrumque Heraclidis Tarentini: croci P. * =; murrae, piperis longi, costi, galbani, singulorum $P$. * = -; cinnamomi, castorei, papaveris lacrimae, singulorum $P . * I$ (Celsus 5.25.10).

If cough prevents sleep the pill of Heracleides of Tarentum relieves both; it contains saffron 0.66 grm., myrrh, long pepper, costmary, galbanum, 1 grm. each, cinnamon, castory and poppy-tears, 4 grms. each.

\subsubsection{Other uses}

We learn from Pliny that poppy was mixed with vinegar for the relief of erysipelas or for the healing of wounds ${ }^{34}$ while Theophrastus mentions that some used the root of the poppy in a posset of mead for epileptics. ${ }^{35}$

Pliny is the only ancient source who refers to a mixture of poppy and wine as an antidote for the stings of scorpions. He adds that the mixture should be

\footnotetext{
$30 \quad$ Pistacia terenbinthus L, see Diosc. 1.71.

31 About 4 grams.

32 Celsus 4.17.1.

33 Plin. HN 6.20.188; Celsus 5.25.9.

${ }_{34} H N$ 6.20.76.201; Diosc. 4.64.4.

35 Theop. HP 9.12.5.
} 
administered immediately. ${ }^{36}$ To extract splinters of bone he recommends the leaves of wild poppy, especially when combined with honey. ${ }^{37}$

Opium 'juice' or latex is an organic substance with alkaline properties, now identified as an alkaloid. Sertürner renamed it and called it morphium after the Greek god of dreams (Morpheus) and in 1816 / 1817 he performed a detailed chemical and pharmacological analysis of this drug (Macht 1915:466). He was the first researcher to laboriously extract the alkaloid.

The five major alkaloids are mainly divided into two distinct chemical classes (Reisine 1996:527) - phenanthrenes (morphine, codeine thebaine) and benzylisoquinolines (papaverine and noscapine). Their narcotic effect descends in this order: morphine has the strongest narcotic effect and thebaine $(0,6 \%)$ the slightest.

Alkaloids make up about $10 \%$ of the dried poppy latex of which morphine, codeine, thebaine and papaverine are the most important with morphine as the principal alkaloid (Van Wyk et al. 2004:369). The scientific formulae for these alkaloids are as follows:

Phytochemistry + pharmacology of poppy

\begin{tabular}{|c|c|}
\hline Alkaloid & Formula \\
\hline Morphine & $\mathrm{C}_{17} \mathrm{H}_{19} \mathrm{O}_{3} \mathrm{~N}$ \\
\hline Codeine & $\mathrm{C}_{18} \mathrm{H}_{21} \mathrm{O}_{3} \mathrm{~N}$ \\
\hline Thebaine & $\mathrm{C}_{19} \mathrm{H}_{21} \mathrm{O}_{3} \mathrm{~N}$ \\
\hline Papaverine & $\mathrm{C}_{20} \mathrm{H}_{21} \mathrm{O}_{4} \mathrm{~N}$ \\
\hline
\end{tabular}

The alkaloid content in the plant is significantly high. Thebaine is known to be a powerful narcotic which induces sleep and relieves pain while papaverine produces a light sleep since it slows the heart rate. Morphine suppresses the central nervous system, mainly in the brain, as well as the cortex and medullar centres, while it stimulates the spinal cord (Dreisbach 1987:324). It modulates the endorphin receptors, which is the main reason why intense pain is relieved with morphine (Van Wyk et al. 2004:369).

\footnotetext{
36 Plin. $H N$ 6.20.80.209.

37 Plin. HN 6.23.63.119; Plin. HN 23.128.
} 


\section{Discussion}

The description above verifies the ancients claims for papaver somniferum in as much as it confirms both its sleep inducing and pain relieving properties. Today we know that the alkaloids of the opium poppy (especially codeine and morphine) are effective narcotics, when used moderately. However, the seeds do not contain any alkaloid and therefore Pliny's claim that the seeds also have a soporific effect, is false. The narcotic effect was most useful during surgery, since the patient fell into such a deep sleep, that he became insensitive to pain. These effects occur due to the enormous alkaloid content in the plant, with morphine as the principal alkaloid. A significant feature of the analgesia is that it occurs without loss of consciousness. The other alkaloids also contribute to the effectiveness of opium as a tranquiliser: Thebaine is a powerful narcotic which induces sleep and renders a patient free of pain. Papaverine also induces a light sleep since it slows the heart rate while narcotine has a depressant action and is also used as a hypnotic drug.

Today the morphine contained in poppy opium remains a major drug in the treatment of intense pain (e.g. post-operative and pain due to terminal illness and cancer). Opioids are, however, not indicated for types of pain which can be treated with a less severe drug like aspirin or a non-steroidal anti-inflammatory drug (Reisine et al. 1996:539). Likewise modern pharmacology prescribes the use of opioid drugs for pain of the uterus only as an obstetrical analgesia to relieve intense labour pains. Although opium will relieve frequency and amplitude of contractions it can, however, lead to neonatal mortality (Reisine et al. 1996:532; 540).

An overdose of papaver somniferum can indeed be fatal and it is therefore quite possible to use the drug in order to commit suicide. An excessive dose of poppy increases the respiratory depressant action, which leads to increased intracranial pressure as a result of retention of carbon-dioxide $\left(\mathrm{CO}_{2}\right)$ and subsequent cerebral vasodilatation until death occurs.

The ancients were also correct in their employment of poppy to treat inflammation. Since papaverine promotes vasodilatation, the resultant increased blood supply to affected areas will decrease inflammation. In modern pharmaceutical practice inflammation will, however, not be treated with poppy, since other anti-inflammatory drugs with less harmful side-effects are now available. Although poppy would be effective, other less drastic drugs are also preferred for the treatment of sciatica and pains in the sides.

For the treatment of erysipelas poppy would, however, not be a good choice of drug. Reisine et al. (1996:533) explains that therapeutic doses of morphine cause dilatation of cutaneous blood vessels, which activates the release of histamine. This results in an allergic reaction, in combination with pruritus and urticaria which would lead to a worsening of the symptoms. 
It also seems that the ancients were correct in their use of poppy in the treatment of colic. Reisine et al. (1996:532) explains that morphine and the other $\mu$ agonists decrease the secretion of acid in the stomach and increase the tone of the stomach. Morphine also decreases secretions of the bile, pancreas and intestine and delays the digestion of food. These effects will indeed relieve the intense pain of colic. Poppy will also cause 'upward'-purging. Today we know that nausea and vomiting are side-effects of morphine-like drugs since it stimulates the chemoreceptor trigger zones for emesis (Reisine et al. 1996:531). The claim for 'downward'-purging is, however, invalid since morphine-like drugs cause constipation. The treatment of diarrhoea with opioids is regarded as rather drastic, since morphine causes inattention to the normal sensory stimuli for the defecation reflex and an increased tone which can even result in a spasm. Propulsive peristaltic waves in the colon are diminished to such an extent that it results in severe constipation (Reisine et al. 1996:532).

Modern descriptions of morphine does not support the claim made by the ancient authors for poppy's ability to relieve bladder problems. Reisine (1996:532) reports that 'morphine inhibits the urinary voiding reflex, and both the tone of the external sphincter and the volume of the bladder are increased'. Urine flow would therefore decrease and the urethra may even become spastic. In effect, the use of poppy will not relieve difficult urination but, on the contrary, intensify the condition and lead to increased pain.

On the other hand the codeine contained in poppy would indeed suppress the cough centre and Scarborough (1995:14) argues convincingly that Dioscorides' mixture (4.64.4) which contained saffron, myrrh and poppy (with its analgesic effects) will prove effective in the treatment of open sores or wounds.

Modern pharmacologists, who have the phytochemistry and pharmacological description of every substance at their disposal, will probably find the idea that poppy could provide relief from epilepsy or extract bone splinters from the body, absurd. They will, however, also be the first to admit that it is a truly remarkable feat that the ancients, relying solely on experimentation and a process of trial and error, correctly identified papaver somniferum as a narcotic, analgesic, anodyne, anti-inflammatory medicine, emetic and anti-diarrhoea medication.

\section{BIBLIOGRAPHY}

Africa, T W 1961. The opium addiction of Marcus Aurelius. Journal of the History of Ideas. 97-102.

Beck, L Y 2005. Pedanius Dioscorides of Anazarbus: De Materia Medica. Hildesheim: Olms-Weidemann. 
Cilliers, L \& Retief, F 2000. Poisons, poisoning and the drug trade. Akroterion. $45,88-100$.

Dreisbach, R H \& Robertson, W O 1987. Handbook of poisoning. 12th ed. Connecticut: Prentice-Hall.

Einarson, B; Link, G K K 1976 - 1990. Theophrastus: Historiae Plantarum. Loeb Classical Library. Cambridge: Harvard University Press.

Einarson, B; Link, G K K 1976-1990. Theophrastus: De Causis Plantarum. Loeb Classical Library. Cambridge: Harvard University Press.

Hallam, G H 1904. The Fasti of Ovid. London: Macmillan and Co.

Kapoor, L D 1995. Opium poppy: Botany, chemistry and pharmacology. New York: Haworth Press Inc.

Kerényi, K 1976. Dionysos: Archetypal image of indestructible life. Princeton: Princeton University Press.

Kritikos, P G and Papadaki, S P 1967. The early history of the poppy and opium. Journal of the Archaelogical Society of Athens, 17-38. http://www.poppies.org/2001/07/13/the-early-history-of-the-poppy-andopium/ Date of access: 7 Feb. 11.

Macht, D I 1915. The history of opium and some of its preparation and alkaloids. JAMA 64:467-471.

Martin, E A 2002. Oxford concise medical dictionary. 6th ed. London: Oxford University Press.

Rackham, H (trans.) 1938. Plinius the Elder: Naturalis Historiae. Loeb Classical Library. Cambridge: Harvard University Press.

Reisine, T \& Pasternak, G 1996. Opioid analgesics and antagonists. 9th ed. In Goodman \& Gillman (eds.), The pharmacological basis of therapeutics. New York: McGraw-Hill.

Retief, F P \& Cilliers, L 2007. Marcus Aurelius se siektegeskiedenis en dood: Was hy 'n opiumverslaafde? Tydskrif vir Geesteswetenskappe 47, 1:56-65.

Sakellarakis, J A 1987. Herakleion museum. Illustrated guide to the museum. Ekdotike Athinon: Athens.

Scarborough, J 1995. The opium poppy in Hellenistic and Roman medicine.

In Porter, R \& Teich, M (eds.), Drugs and narcotics in history. 4-23. Cambridge: University Press.

Siegel, R E 1976. Galen on the affected parts. Basel: S Karger.

Sneader, W 2005. Drug discovery: A history. Chichester: John Wiley \& sons Ltd.

Spencer, W G (trans.) 1938. Loeb Classical Library. Celsus: De Medicina.

Classical Library. Cambridge: Harvard University Press

Spencer, W G 1948. Celsus: De Medicina. Loeb Text. London: Heinemann.

Van Wyk, B E \& Wink, M 2004. Medicinal plants of the world. Pretoria: Briza Publications. 